\title{
Efficiency of Using Some New Insecticides against Cotton Leaf Worm (Spodopteralittoralis) Based on Biochemical and Molecular Markers
}

\author{
Heidi A. Ali ${ }^{1}$, Ahmed M. Kordy ${ }^{2}$, Ahmed E. Khaled ${ }^{3}$, Nabeill A. Hassan ${ }^{1}$, Nader R. Abdelsalam ${ }^{3}$
}

\begin{abstract}
Bioassays were carried out for evaluating the toxicity of different insecticides against the susceptible strain of cotton Leafworm, Spodoptera littoralis (Boisd.). Toxicity data based on $\mathrm{LC}_{50}$ values indicated that the proclam ${ }^{\circledR}$ is more toxic insecticide against the laboratory strain, while, the OP syclon $^{\circledR}$ was less toxic. Esterase isozymes exhibited a wide range of variability among the pupae and larvae. Two common bands were detected among all samples in pupae and larvae. Proclam showed one band in pupae $\left(\right.$ Es. $\left.C_{2}\right)$ compared with other treatments and in larvae detected one band in $\left(\right.$ Es. $\left.C_{3}\right)$ and detecte the highest band number (6 bands) comparing with other insectcides. The results of biochemical analysis showed that there is arelationship between the resistance to insecticide and the increase of enzyme activity such as esterase enzyme. Five out of ten oligonucleotide primers $(50 \%)$ used in the RAPD analysis gave unique markers. Out of the five primers, two detected single unique markers (OPA-02 and OPA-15), two gave two markers (OPA-05 and opc-02), and one yielded three unique markers (OPC-12).Additionally, compared with the control worms, cotton leaf worm exposed to insecticides recorded the emergence of 7 new fragments from 98 total fragments. So, the total number of fragments which disappeared in response to both treatments was 98 fragments. Exposure to insecticides at all concentrations revealed the increase or decrease the number of amplified polymorphic DNA and increased gene expression in comparison to control cotton leaf worm.
\end{abstract}

Key words: Cotton leaf worm, Spodopter alittoralis, bioassay, esterase Isozymes and RAPD

\section{INTRODUCTION}

The cotton leafworm Spodoptera littoralis (Boisd.) (Lepidoptera: Noctuidae) is a prolific and highly polyphagous insect. It is considered to be a major pest of great economic importance in many countries since it attacks a multitude of host plants $(\sim 73)$. The damage is mainly defoliation since the larvae (caterpillars) are principally leaf feeders and those larvae also have the habit of boring into and feeding in the interior of fruits such as tomato, young melon and pepper which near to or rest on soil (Kandil et al., 2003). The use of insecticides is still having an important role in controlling such insect-pest. Foliar applied insecticides are necessary when the economic threshold is exceeded. Therefore, insecticides are currently the principle method for controlling the Egyptian cotton leafworm in Egypt and will likely continue to be used until more biologically based management systems could be developed (Alotaibi, 2013).

Isozymes defined as multiple forms of enzymes in the same organism and having similar or identical catalytic activity. It is important to notice that enzyme analysis by electrophoresis offers very well defined and effective tools for detection of genetic differences among individuals(Shaw and Kaen, 1967). Genotype identification, based on morphological characteristics of insects, and plants, is often subjected to errors caused by variable environmental conditions. These errors are increased if the genotypes are of a similar origin. Electrophoresis and other techniques have been widely used to group and identify genotypes.Isozymes loci are excellent biochemical markers since they are usually co dominantly inherited, do show pleiotropic effects, rarely exhibit epistasis and are not affected by the environment. Isozymes have been used very successlly in certain aspects of plant breeding and genetics as nearly neutral genetic markers (Tanksley, et al., 1989).Esterase, proxidase are a ubiquitous enzyme found in plants, mammals, fungi and prokaryotes. It catalyzes the oxidation of cellular component. Esterase from many insects' sources has been shown to consist of isozymes, which existed in both anionic and cationic iso- esterase. Esterase isozymes have been reported to occur in both soluble and bound forms, the bind enzymes are associated with the cell walls, bounded by ionic interaction to the cell wall in the undamaged cell with respect to physiological functions(Brewbaker, 1966).

Random Amplified Polymorphic DNA (RAPD) is a PCR-based technique for DNA fingerprinting. This assay, unlike the PCR, does not require knowledge of the target DNA sequence, and a single arbitrary primer will support DNA amplification from a genomic template if binding sites on opposite strands of the

\footnotetext{
${ }^{1}$ PlantProtection Research Institute,Agric. Res. Center, Egypt;

${ }^{2}$ Plant Protection Department, Faculty of Agriculture (SabaBasha),

Alexandria University, Egypt;

${ }^{3}$ Agricultural Botany Department, Faculty of Agriculture

(Saba-Basha), Alexandria University, Egypt.

(Corresponding Author: nader.wheat@yahoo.com).

Received October 26, 2015, Accepted November19, 2015
} 
template exist within a distance that can be traversed by the thermo stable equation usually random oligonucleotides (or 10 bases) used as primer to amplify discrete fragments of genomic DNA. Random amplified polymorphic DNA (RAPD) markers can be used to detect DNA polymorphism without the need for predetermined genetic data. Each product is derived from a region of the genome that contains two short segments in inverted orientations, on opposite strands that are complimentary to the primer and sufficiently close together for the amplification to work.(William et al., 1990; Welsh and McClelland, 1990).RAPD is one of the widely used molecular markers, where it was applied in: determination of paternity and kinship relationships, gene mapping, identification of markers linked to traits of interest without the necessity for mapping the entire genome, plant and animal breeding, to understand the complexity of the transmission cycles of insects vectors and population and evolutionary genetics (Marcili et al., 2009 and Sharma et al., 2009). Random amplified polymorphic DNA (RAPD) analysis has proved useful for estimating genetic diversity particularly to assist in the conservation of rare species and plant genetic resources (Anderson and Fairbanks, 1990).

Molecular techniques help researchers not only to identify the genotypes, but also in assessing and exploiting the genetic variability through molecular markers (Whitkuset al., 1994). Genetic markers are of great value in genetic research and practical breeding programs, since they reflect the genetic variation among individuals. Morphological markers, or mutations in morphological markers, or mutations in genes with visible consequences, have been used in genetic studies since early in the twentieth century (Hussiumet al., 2000). The molecular biology tools provide detailed information about the genetic structure of natural population, which was not available in the past. Such studies help to find new and useful genes, and also provide information about the phylogenetic relationship. Secondly, in case of the large size germplasm it becomes a critical step for selection of parental genotypes from the germplasm (Beckman et al., 1998). The effects of four insecticides on feeding and growth of cotton leafworm, Spodoptera littoralis (Boisd.), larvae were investigated during the fourthinstar larvae. Biochemical and molecular studies were done todetecte the efficiency of using some new insecticides against Cotton Leaf Worm (Spodopter alittoralis) based on Biochemical and Molecular markers.

\section{MATERIALS AND METHODS}

The current study was carried out in the Agricultural
Botany Department, Faculty of Agriculture (Saba Basha), Alexandria University, Alexandria, Egypt and Plant Protection Department Faculty of Agriculture (Saba Basha), Alexandria University, Alexandria, Egypt during the period of 2014-2015 in three different experiments to detect the efficiency of using some new insecticides against Cotton Leaf Worm (Spodoptera littoralis) based on biochemical and molecular markers.

\section{A- Tested insect and Insecticides}

Susceptible strain of $S$. littoralis was mass reared in the laboratory under the higrothermic conditions of $25 \pm$ $2^{\circ} \mathrm{C}$ and $75 \pm 5 \%$ R.H. as described by El-Defrawi (1964). The larvae were fed on castor oil-bean leaves (Ricinus communis L.) and kept in 1 liter glass jars covered with muslin which fixed tightly by a rubber band. The number of larvae per jar was differed according to the developing instar. After pupation, the resulting pupae were sexed and grouped in groups of 12 pupae at a sex ratio of $29: 1 \sigma^{\hat{\sigma}}$ and then placed in the glass jar. After the emergence of the moths, they were supplied with a piece of cotton moistened with $10 \%$ sugar solution and paper strips to act as sites for egg deposition. The deposited egg masses were daily collected and left till hatching. The newly hatched larvae were transferred to clean jar and supplied with fresh leaves. The different larval instars were differentiated according to Willcocks and Bahgat (1937).

Progressive dilutions of the four tested insecticide were prepared in distilled water. All compounds were tested against the $4^{\text {th }}$ instar larvae of the cotton leafworm (S. littoralis). Nutritional indices were measured regularly throughout the feeding tests until pupation. The food consumed by larvae in most insecticidetreatments was below that of control. emamectin benzoate (proclam $^{\circledR} \quad 5 \%$ sg), methomyl (newmyl ${ }^{\circledR}$ $90 \%$ ), chlorpyrifos $\quad$ (teraguard $^{\circledR} \quad 48 \%$ ) and lambdacyhalothrin $\left(\right.$ syclon $^{\circledR} 5 \%$ ) as shown in Table, 1 . Treatments seemed to be the best feeding deterrents.

The leaf-dipping bioassay method was used to determine the median lethal concentration (LC50) values. Series of concentrations (in water) of the tested formulated compounds were prepared. Castor-bean leaves were dipped for 30 seconds in each concentration then left for one hour to dry. The treated leaves were offered to newly moulted 4th instar larvae of succuptable strain. Mortality percentages were recorded after 24,48,72 and $96 \mathrm{hrs}$ and corrected according to (Abbott,1925). To estimate the LC50 values, the data were analyzed using an adopted computer program based on a standard implementation of the probit analysis recommended by Finney (1971). Estimates of the $\log$ dose/mortality $\%$ are expressed as the Normal Equivalent Deviate (N.E.D.). 
Table 1. The tested chemical insecticides used in the study

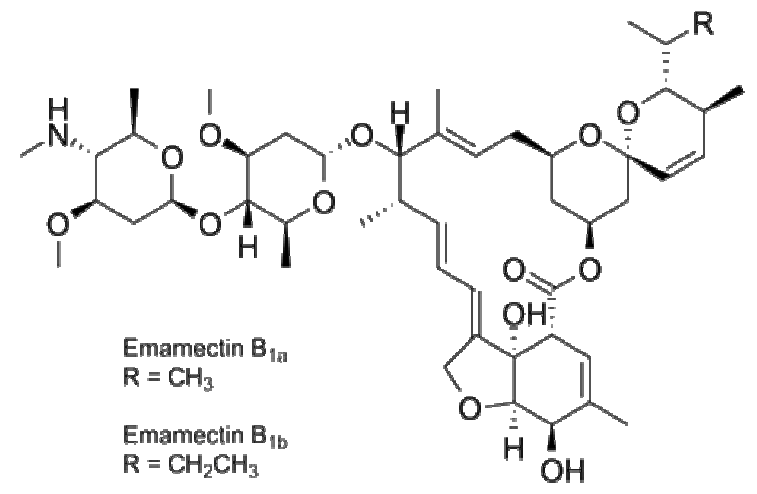

Emamectin benzoate proclaim $5 \%$ SG

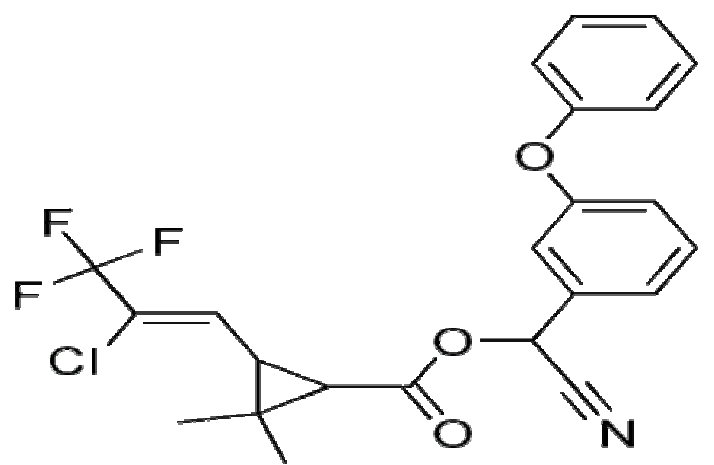

Lambda-Cyhalothrin Syclon ${ }^{\mathbb{2}} \% \mathrm{SC}$

* $\mathrm{SG}=$ soluble granules, $\mathrm{SP}=$ soluble powder, $\mathrm{SC}=$ soluble

The median lethal dose $\left(\mathrm{Lc}_{50}\right)$ and its fiducial limits, the interception (a) and slope (b) parameters for the tested compounds were also calculated.

\section{B- Biochemical studies (Isozymes electrophoresis):}

Agar-starch-polyvinyl pyrolidine (PVP) gel electrophoresis was carried out according to the procedures described by Shaw and Kaen (1967) and Andrews (1981). Buffer was prepared by dissolving $92.75 \mathrm{~g}$ of $0.3 \mathrm{M}$ Boric acid and $12 \mathrm{~g}$ sodium hydroxide in 5 liters of distilled water, then the solution was adjusted to $\mathrm{pH}=8.3$. The used gel buffer was $0.07 \mathrm{M}$ Tris $0.007 \mathrm{M}$ citric acid $(\mathrm{pH}=8.3)$. One liter of the gel buffer was prepared by dissolving $9.21 \mathrm{~g}$ Tris, $1.05 \mathrm{~g}$ citric acid in distilled water, and kept in a refrigerator until experimental use. Agar-starch-polyvinyl pyrolidine (P.V.P) gel was prepared by dissolving $1.0 \mathrm{~g}$, $0.5 \mathrm{~g}$ P.V.P. and $0.5 \mathrm{~g}$ of hydrolyzed starch with $10 \mathrm{ml}$ electrode buffer and $90 \mathrm{ml}$ distilled water. The mixture was shaken vigorously and cooked in a boiling water bath until the solution become transparent. The hot liquid gel was poured on glass plates $(20 \times 30 \mathrm{~cm})$ to<smiles>CNC(=O)O/N=C(\C)SC</smiles><smiles>CNC(=O)O/N=C(/C)SC</smiles>

Methomyl: Newmyl ${ }^{\circledR}$ 90\% SP<smiles>CCOP(=S)(OCC)Oc1nc(Cl)c(Cl)cc1Cl</smiles>

Chlorpyrifos Teraguard $^{\circledR} 48 \%$ EC

concentrate and $\mathrm{EC}=$ emulsfiable concentrate produce a smooth surface layer with thickness of 0.8-0.9 mm and they were kept at $4{ }^{\circ} \mathrm{C}$ until usage (El-Metainy et al., 1977). Electrophoresis experiments were conducted in an incubator refrigerator adjusted at $4^{\circ} \mathrm{C}$ using a 250 volts AC electrical current, with constant voltage throughout the 90 minutes of the running period. Phosphate buffer with $0.1 \mathrm{M}$ at $\mathrm{pH}=7.0$ was used as a staining buffer by adding $39 \mathrm{ml}$ of $0.1 \mathrm{M}$ solution of monobasic sodium phosphate to $61 \mathrm{ml}$ of $0.1 \mathrm{M}$ solution of sodium dibasic phosphate and completed to a final volume of $200 \mathrm{ml}$ with distilled water(Youssef et al., 1989).

\section{C- Molecular studies:}

The chemicals were obtained from Sigma Scientific, extraction kit, colored and clear master mix, 10X TBE buffer ( $\mathrm{pH} 8.0$ ), Ethidum bromide, 100bp DNA ladder Agrose were provided from iNtRON Biotechnology, Inc (Germany).Genomic DNA was extracted from tissues of the Spodoptera littoralis samples using genomic DNA extraction kit (G-Spin) TM for cell/ tissue extraction (iNtRON Biotechnology,Inc). Kits are designed for 
rapid isolation of genomic DNA from various sample sources included fresh or frozen animal cells/tissues (for cell/tissue). RAPD analysis was carried out using 10 oligonucleotide primers (Table 2) were selected from the Operon Kit (Operon Technologies Inc., Alabameda, $\mathrm{CA})$. The polymerase chain reaction mixture $(25 \mu \mathrm{l})$ consisted of $0.8 \mathrm{U}$ of Taq DNA polymerase; 25 pmoldNTPs; 25 pmol of primer and $50 \mathrm{ng}$ of genomic DNA. PCR amplification was performed in a Biometra T1 gradient thermalcycler for 40 cycles after initial denaturation for $3 \mathrm{~min}$ at $94^{\circ} \mathrm{C}$. Each cycle consisted of denaturation at $94^{\circ} \mathrm{C}$ for $1 \mathrm{~min}$; annealing at $36^{\circ} \mathrm{C}$ for 1 min; extension at $72^{\circ} \mathrm{C}$ for $1 \mathrm{~min}$ and final extension at $72^{\circ} \mathrm{C}$ for $10 \mathrm{~min}$ (Soliman, et al., 2003). Amplification products were separated on $1.5 \%$ agarose gels at 80 volts for $1.30 \mathrm{hrs}$ with $1 \mathrm{X}$ TBE buffer. To detect ethidium bromide/DNA complex, agarose gels were examined on ultraviolet transilluminator $(302 \mathrm{~nm}$ wavelength) and photographed. Using 100pb DNA ladder, the lengths of the different DNA fragments were determined. RAPD fragments were scored as present/absent band using gel analyzer program. Fragment scoring and lane matching were performed automatically on digital images of the gels, using Phoretix 1D advanced Version 4.00 (Phoretix International, Newcastle upon Tyne, UK). Clustering methods and similarity coefficients are described as given by Rohlf, (2000).

Table 2. RAPD primers sequences used for analysis

\begin{tabular}{ll}
\hline Primer & Sequences \\
\hline OPA-02 & $\mathbf{5}$ CAT CCC CCT G 3` \\
\hline OPA-03 & $\mathbf{5}$ ' TTC GAG CCA G 3` \\
\hline OPA-04 & $\mathbf{5}$ ' GTG AGG CGT C 3` \\
\hline OPA-05 & $\mathbf{5}$ AGG GGT CTT G 3` \\
\hline OPA-15 & $\mathbf{5}$ TTC CGA ACC C 3` \\
\hline OPC-01 & $\mathbf{5}$ TGA TCC CTG G 3` \\
\hline OPC-02 & $\mathbf{5}$ CAT CCC CCT G 3 \\
\hline OPC-03 & $\mathbf{5}$ ' GGG GGT CTT T 3` \\
\hline OPC-12 & $\mathbf{5}$ TGT CAT CCC C 3` \\
\hline
\end{tabular}

RESULTS AND DISCUSSION

\section{A- Evaluation of pesticides against the cotton leafworm Spodoptera littoralis (Boisd.)}

The estimated values of the Normal Equivalent Deviation (N.E.D) (response/log dose regression) and $\mathrm{Lc}_{50}$ of the four different insecticidal tested against the $4^{\text {th }}$ larval instar of the succeptable strain of cotton leafworm. In the present studies Table (3) showes that the susceptibility of the four tested compounds used in the present work caused variable toxic effects against the $4^{\text {th }}$ larvae of Spodoptera littoralis for succeptable strain.

The first tested compound teraguard ${ }^{\circledR}$ (Chlorpyrifos ) is active by contact, ingestion, and vapor action. It inhibits an enzyme of the nervous system (acetylcholine esterase); this causes convulsions and paralysis. The second tested compound include newmyl ${ }^{\circledR}$ (Methomyl) similar to other carbamateinsecticides, methomyl inhibits acetylcholinesterase (AChE), which is contained within synaptic junctions between neurons (Kuhr and Dorough 1976). The third tested compounds have syclon $\AA$ (Lambda-Cyhalothrin). Pyrethroids are axonic poisons that affect the nerve fiber by binding to a protein thatregulates the voltage-gated sodium channel. Normally, this gate opens to cause stimulationof the nerve and closes to terminate the nerve signal. The channels are pathwaysthrough which ions are permitted to enter the axon and cause excitation. Finally, the last tested compound has the proclam ${ }^{\circledR}$ (Emamectin benzoate)which is a novel semi-synthetic derivative of the natural product abamectin in the avermectin family of 16-membered macrocylic lactones.Avermectins are a family of 16-membered macrocyclic lactone natural product homologues produced by thesoil microorganisms, Streptomyces avermitilis. Isolation ofthe crude fermentation product of $S$. avermitilisyieldeda complex of eight closely related avermectinhomologues (A1a, A1b, A2a, A2b, B1a, B1b, $\mathrm{B} 2 \mathrm{a}$, andB2b), of which avermectins B1 ( $\mathrm{a}$ and $\mathrm{b}$ ) were the majorcomponents. The anthelmintic properties of the avermectins are due predominantly to potentiation and/or direct opening of glutamate-gated chloride channels, whereas in insects, it is likely that avermectins bind to multiple sites (including glutamate and GABA) in insect chloride channels. In general, the chloride ion flux produced by the opening of the channel into neuronal cells results in loss of cell function and disruption of nerve impluses.

The LC50 values were $0.0178,6.08,6.75$ and 10.77 ppm for proclam $^{\circledR}$, teraguard $^{\circledR}$, teraguard $^{\circledR}$ and syclon ${ }^{\circledR}$ after 96 hrs post- treatment, respectively.Comparing the tested compounds based on their $\mathrm{Lc}_{50}$ values, it was found that (proclam ${ }^{\circledR}$ ) was more toxic than other tested compounds. Whereas, the less toxic compound achevied by syclon ${ }^{\circledR}\left(\mathrm{Lc}_{50}=10.77 \mathrm{ppm}\right)$ when determined $\mathrm{LC}_{50}$ after $96 \mathrm{hrs}$ post- treatment(Table 3 ).

The obtained resutls agreed with (Muthusamy et al., 2011) who found dichlorvos was be more toxic as compared to temephos and lambda-cyhalothrin. But, the obtained results differ with(El- Sheikh,2012) who found the pyrethroid Cyper (Cypermethrin 10\% EC) is more toxic insecticide against the laboratory strain of Spodoptera littoralis, while, the OP Dursban H- 48\% 
EC (Chlorpyrifos) was less toxic. Whereas, Bengochea et al.,(2014) found that emamectin benzoate is not only a useful insecticide when ingested by beet armyworm larvae but it also has ovolarvicidal and adult activity. Finally, Vojoudi et al., (2011) showed that chlorpyrifos and spinosad were more effective insecticides against $3^{\text {rd }}$ instar larvae of cotton bollworm compared to abamectin based on formulated materials. On the other hand Gamil et al., (2011) studied the efficacy of Avaunt ${ }^{\circledR}$ (Indoxacarb $15 \%$ EC) on newly ecdysed $2^{\text {nd }}$ and $4^{\text {th }}$ instar Spodoptera littoralis (Boisd.) Whereas, the bioassay showed that $2^{\text {nd }}$ instars were more susceptible than the $4^{\text {th }}$ instars as the $\mathrm{LC}_{50}$ and $\mathrm{LC}_{90}$ values were 0.63 and $3.1 \mathrm{ppm}$ for $2 \mathrm{nd}$ instar larvae and 2.0 and $18.75 \mathrm{ppm}$ for 4 th instar larvae, respectively. Finally, http://www.sciencedirect.com/science/article/pii/S0261 219414003342 - cor1El-Sheikh (2015) investigated the comparative effectiveness of some new insecticides including emamectin benzoate, lufenuron, and spinosad against $3^{\text {rd }}$ and $5^{\text {th }}$ larval instars of Spodopteralittoralis. Also,determined Time-mortality relationships, effects on larval weight gain, feeding damage, and larval development of $S$. littoralis.

\section{B- Biochemical studies:}

Biochemical methods provide more specific information about the resistance potential or the development of resistance in field populations of living organisms. Esterase iso-enzyme assay was applied as the most appropriate technique for the evaluation some insecticide on cotton leafwormSpodoptera littoralis.As conventional symbols in electrophoresis analysis, a pattern was first described in terms of Anodal (A) or Cathodal (C) zones according to their direction of mobility in the electrophoresis field. Each zone is assigned for a locus coding for aesteraseisozymes. The locus with the least migration is designated the first; the next one is the second, and so on. In contrast, as shown in Figure 1, esterase isozymes exhibited a wide range of variability among the pupae and larvae. Two common bands were detected among all samples in pupae and larvae (Es. $C_{1}$ and Es. $A_{1}$ ). Proclam showed one band in pupae $\left(\right.$ Es. $\left.\mathrm{C}_{2}\right)$ compares with other treatments and in larvae detected one band in $\left(\right.$ Es. $\left._{3}\right)$ and detecte the highest band number ( 6 bands) comparing with other insectcides. The results of biochemical analysis showed that there is relationship between the resistance to insecticide and the increase of enzyme activity such as esterase enzyme as showed in the previous figure. Esterase enzymes play an important role in conferring or contributing to insecticide resistance in insects.

Table 3. Toxicity of some insecticides against the $4^{\text {th }}$ instar larvae of the cotton leafworm Spodoptera littoralis.

\begin{tabular}{lccccc}
$\begin{array}{c}\text { Tested } \\
\text { compound }\end{array}$ & $\begin{array}{c}\text { Bioassay Time } \\
\text { (hrs) }\end{array}$ & $\begin{array}{c}\text { N.E.D. (response)/ } \\
\text { log(dose)regression }\end{array}$ & LC $_{\mathbf{5 0}}$ & $\begin{array}{c}\text { 95\% fiducial limits } \\
\text { Lower Upper }\end{array}$ \\
\hline Newmyl & 96 & $\mathrm{Y}=-1.339+1.638 \mathrm{x}$ & $6.75 \mathrm{ppm}$ & 9.86 & 4.46 \\
\hline Teraguard & 96 & $\mathrm{Y}=-0.728+0.929 \mathrm{x}$ & $6.08 \mathrm{ppm}$ & 31.48 & 2.22 \\
\hline Syclon & 96 & $\mathrm{Y}=-7.053+6.832 \mathrm{x}$ & $10.77 \mathrm{ppm}$ & 12.08 & 9.61 \\
\hline Proclam & 96 & $\mathrm{Y}=11.589+6.631 \mathrm{x}$ & $0.0178 \mathrm{ppm}$ & 0.0196 & 0.0163 \\
\hline
\end{tabular}

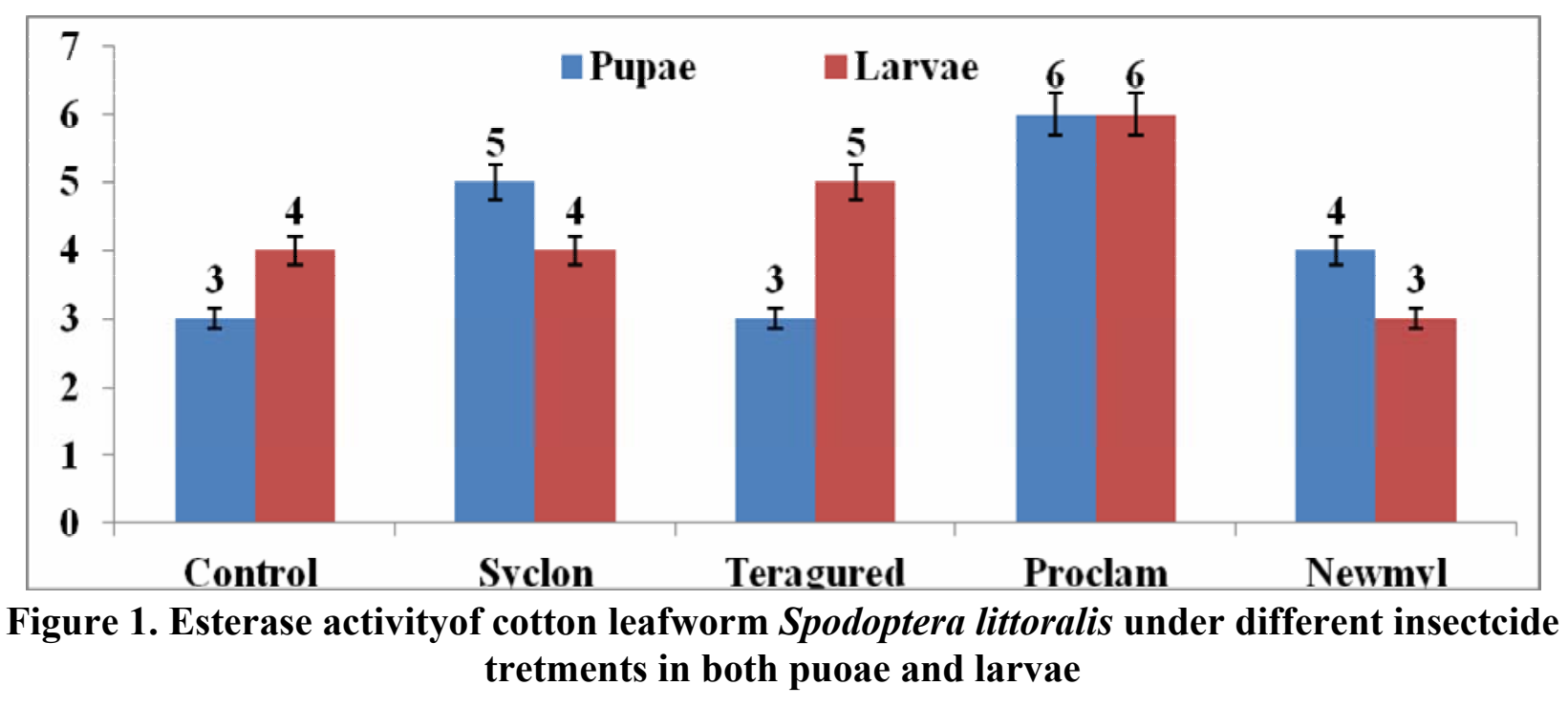


This has been shown in aphid Myzuspersiace (Field and Devonshire, 1998), mosquitoes, Culexquinquefasciatus and C. pipiens (Guillemaudet al., 1997), blowfly, Luciliacuprina (Campbell, 1998) and housefly Muscadomestica (Taskin and Kence, 2004). In insects, the esterase enzyme patterns have shown high rates of intraspecific and interspecific variations (Nascimento and Campos Buicudo, 2002). Possibly, gene duplication followed by divergence of duplicated genes from the ancestral gene is the origin of at least part of this variability (Oakeshott et al., 1993; Nascimento and Campos Bicudo, 2002).

There are several methods that have been developed for detecting resistance in insects. Usually, laboratory bioassays are performed on the progeny of field collected insects for detecting insecticide resistance. Traditional bioassay methods depend on measuring of LD50 or LC50 values, which are based on the criteria of insecticide amount required for killing $50 \%$ of a test population. In order to determine the resistance ratio of a field population, these values are divided by the LC50 of a susceptible laboratory population. Although these bioassays are easy to perform, they have several disadvantages. First, they are time- consuming since they need many individuals for testing one insecticide. Second, and most importantly, they do not provide a quantitative measure of potential resistance in individual strains or clones. On the other hand, biochemical methods and molecular biological techniques overcome these disadvantages in many aspects by reducing the sample size and giving more specific information about the resistance potential or the development of resistance in field populations (Kristensen, 2005 and Han et al., 1998). In this study, the biochemical basis of some insecticide resistance and the esterase enzyme patterns were investigated.

\section{C- Randomly amplified polymorphic DNA (RAPD) analysis}

Cotton leaf worm (Spodoptera littoralis) has been proven to be important insect in experimental laboratory work not only for cytotoxicological and different genetic studies, but also for biochemical and molecular research. The use of Cotton leaf worm cells for the study of genotoxic effects has only recently been explored. RAPD-PCR was performed on cotton leaf worm genome to evaluate the genomic toxicity occurred to cotton leaf worm obtained from treatment with syclon, teraguard, proclaim, and newmyl at $\mathrm{LC}_{50}$. insecticides compared with those obtained from control one. In the current study in Figure 2 and Table 3, five out of ten oligonucleotide primers $(50 \%)$ used in the RAPD analysis gave unique markers. Out of the five primers, two detected single unique markers (OPA-02 and OPA-15), two gave two markers (OPA-05 and opc-02), and one yielded three unique markers (OPC-12).Additionally, compared with the control worms, cotton leaf worm exposed to insecticides recorded the emergence of 7 new fragments from 98 total fragments. So, the total number of fragments which disappeared in response to both treatments was 98 fragments. Exposure to insecticides at all concentrationsrevealed that increase or decrease the number of amplified polymorphic DNA and increased gene expression in comparison to control cotton leaf worm. The results of the present study exposed that proclaminsecticide caused oxidative stress which up regulated gene expression.

According to the cluster analysis in Figure 4 the data divided to two main groups by $72 \%$ similarity, the first group includes the insecticide newmyle and the other one divided by two other groups includes the proclam insecticide as individual one by $77 \%$ and the other groups includes control, tetrgrade and syclon by $84 \%$. The similirty between teraguard and syclon was $96 \%$. The data showed that proclaim was in one cluster by general similirty $56 \%$ as shown in Table( 4).

The present results are in aline with Atienzar et al., (2002) assayed and related the random amplified polymorphic DNA (RAPD) to detect genotoxin-induced DNA damage and mutations. The changes occurring in RAPD profiles following genotoxic treatments include variation in band intensity as well as gain or loss of bands.Also, Mironenko et al., (2007) used random amplified polymorphic DNAs (RAPDs) to study the genetic variation of Pyrenophoratritici-repentis isolates causing wheat tan spot. Our finding agree withBaurand et al., (2015) showed the study explores the relevance of coupling RAPD and a High-Resolution capillary electrophoresis System (HRS) method for assessing the genotoxic potential of the wide variety commercial formulations of pesticides. The results agree withErcan, (2015)who detected DNA damage in Ephestiakuehniella by RAPD-PCR Abstract. The random amplified polymorphic DNA (RAPD) assay is a useful method for detecting genotoxin-induced DNA damage.Our results is agree with Anderson and Fairbanks, (1990) who reported that Random amplified polymorphic DNA analysis has proved useful for estimating genetic diversity particularly to assist in the conservation of rare species and plant genetic resources.The development of random amplified polymorphic DNA (RAPD) markers, generated by the polymerase chain reaction (PCR), allows the examination of genomic variation without prior knowledge of DNA sequences (Hadrys, 1992). The results proved the same fact withHadrys et al., 
(1992)that developed molecular genetic markers into powerful tools to analyse genetic relationships and genetic diversity. Also, Abdel-Wahed, et al., (2013)studied the $6^{\text {th }}$ instar larvae of Spodopteralittoralis treated in $2^{\text {nd }}$ instar larvae with $\mathrm{LC}_{50}$ of Match and Protecto at $0.0057 \mathrm{ppm}$, and 0.1099 $\mathrm{gm} / \mathrm{ml}$., respectively, Five random primers were used in this study to generate a fragmenting pattern as a tool to investigate the molecular differences between treated samples and control. The numbers of unique and common fragments generated by using these primers (OPO1, OPO2, OPO3, OPO4 and OPO5) was recorded. It has been found that primer OPO2 was the most powerful in generating a unique informative fragmenting pattern, it gave 4 specific unique fragments. The primer OPO4 was the poorest one in generating an informative fragmenting pattern.

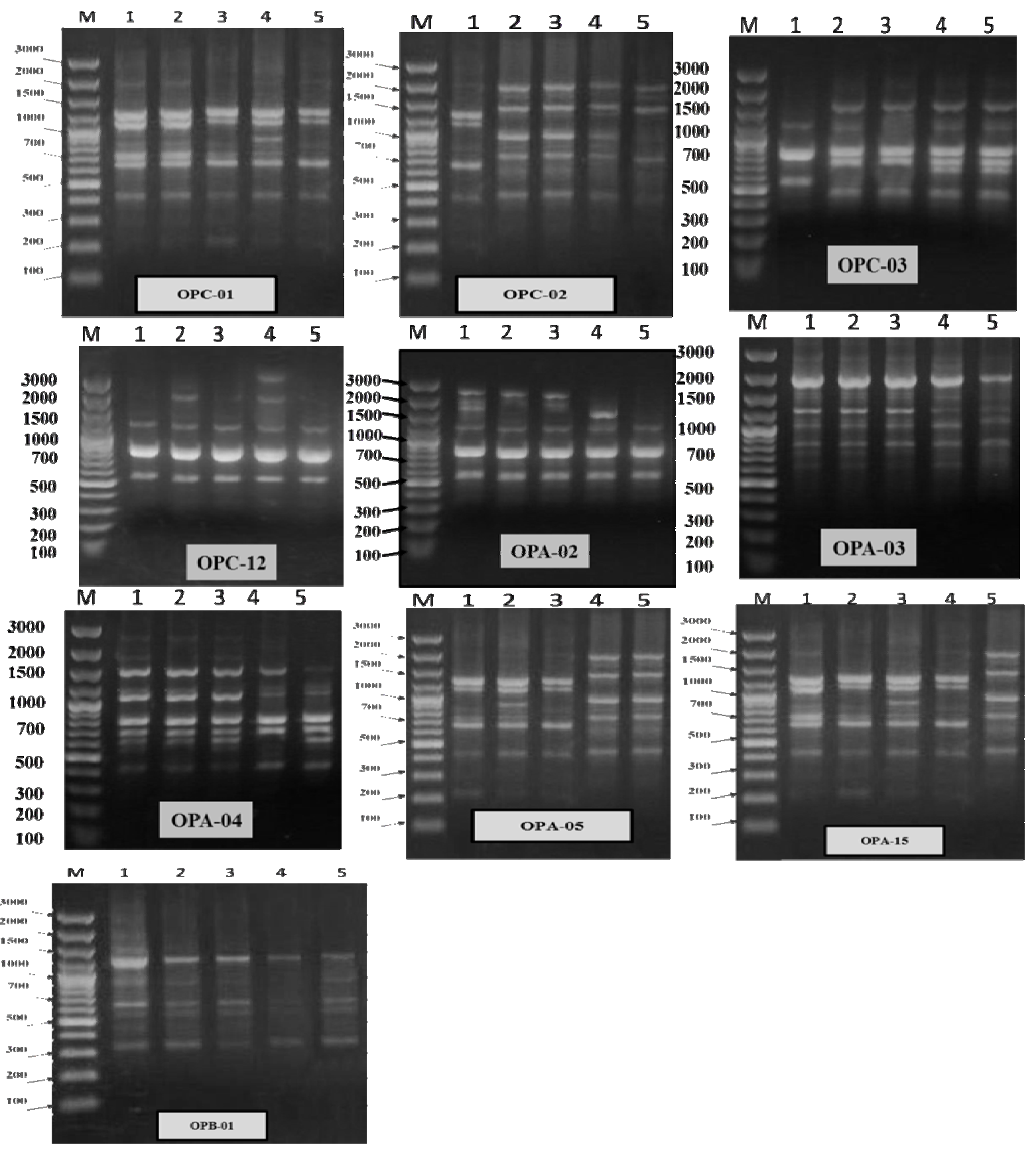

Figure 2. DNA polymorphism of the $4^{\text {th }}$ instar larvae of the cottonleaf worm (Spodoptera littoralis)treated with insecticides using randomly amplified polymorphic DNA 
Table 4. Number of scorable bands, Polymorphic, Monomorphic bands and Percentage of polymorphism for cottonleaf worm (Spodoptera littoralis)

\begin{tabular}{lccccc}
\hline Markers & $\begin{array}{c}\text { Number of } \\
\text { scorable bands }\end{array}$ & $\begin{array}{c}\text { Polymorphic } \\
\text { bands }\end{array}$ & $\begin{array}{c}\text { Monomorphic } \\
\text { bands }\end{array}$ & Unique band & $\begin{array}{c}\text { Percentage of } \\
\text { polymorphism (\%) }\end{array}$ \\
\hline OPA-02 & 14 & 9 & 5 & $1(2168$ bp.) & $64 \%$ \\
\hline OPA-03 & 11 & 10 & 1 & & $91 \%$ \\
\hline OPA-04 & 9 & 7 & 2 & $2(1957 \& 1638 \mathrm{bp})$. & $83 \%$ \\
\hline OPA-05 & 6 & 5 & 1 & $1(712 \mathrm{bp})$. & $44 \%$ \\
\hline OPA-15 & 9 & 4 & 5 & $2(1318 \mathrm{bp})$. & $60 \%$ \\
\hline OPC-01 & 10 & 6 & 4 & & $40 \%$ \\
\hline OPC-02 & 10 & 4 & 6 & $2(29590 \& 2000 \mathrm{bp})$. & $75 \%$ \\
\hline OPC-03 & 12 & 9 & 1 & and $1(2000 \mathrm{bp})$. & $90 \%$ \\
\hline OPC-12 & 10 & 9 & 4 & -- & $42 \%$ \\
\hline OPB-01 & 7 & 3 & 32 & - \\
\hline Total & 98 & 66 & & & \\
\hline
\end{tabular}

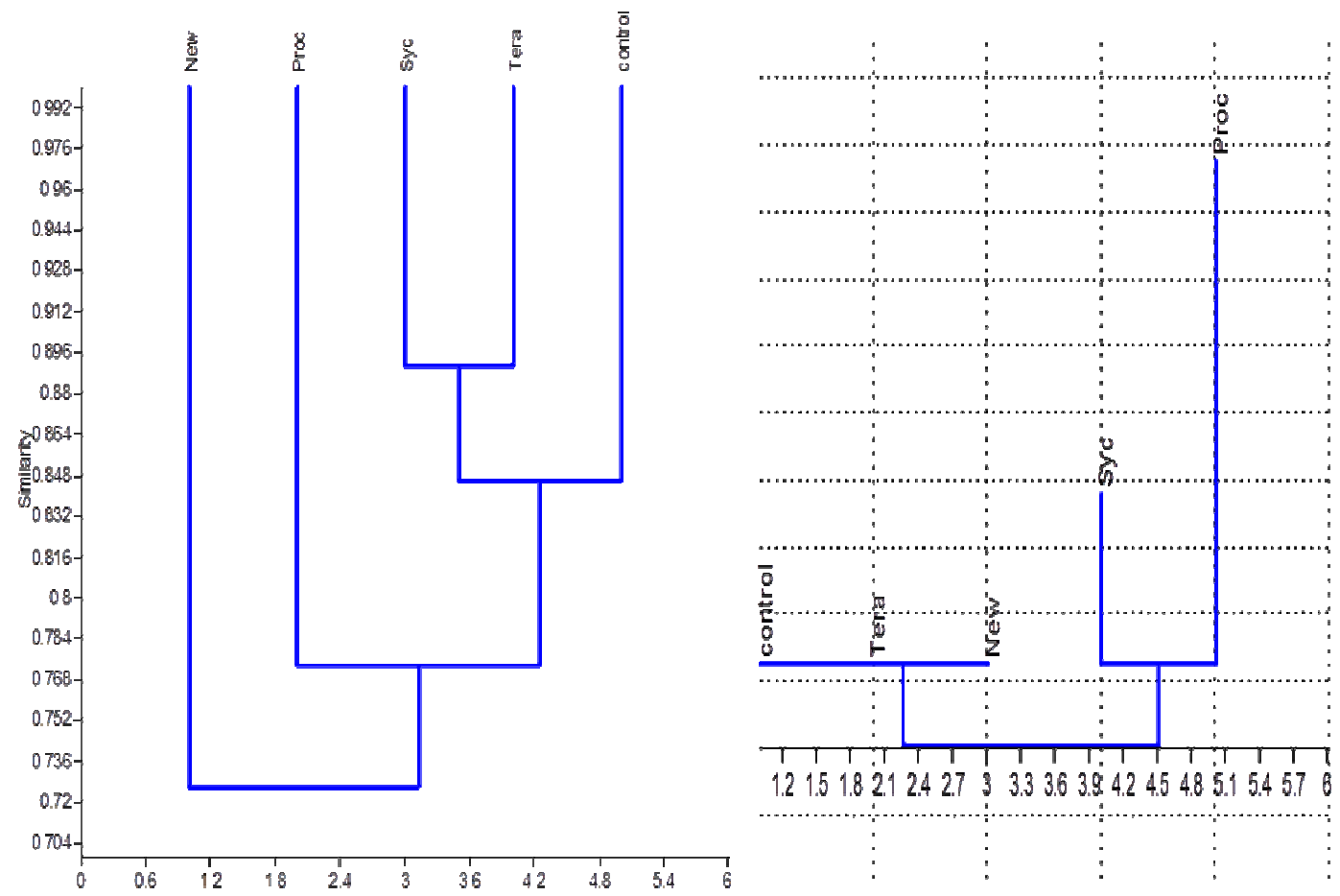

Figure 3. Cluster analysis and similirty for cottonleaf worm (Spodoptera littoralis) treated with four incetcides

Table 5. Similarity indices (\%) among fourinsecticidesbased on 10 RAPD primers

\begin{tabular}{lccccc}
\hline & Control & Syclon & Teraguard & Proclam & Newmyl \\
\hline Control & 1 & 0.73171 & 0.72093 & 0.58696 & 0.45238 \\
\hline Syclon & 0.73171 & 1 & 0.80247 & 0.61798 & 0.55844 \\
\hline Teraguard & 0.72093 & 0.80247 & 1 & 0.63043 & 0.51807 \\
\hline Proclam & 0.58696 & 0.61798 & 0.63043 & 1 & 0.56962 \\
\hline Newmyl & 0.45238 & 0.55844 & 0.51807 & 0.56962 & 1 \\
\hline
\end{tabular}




\section{REFERENCES}

Abbott, W.S. (1925). A method of computing the effectiveness of an insecticide.Journal of Economic Entomology.18: 265-267.

Abdel-Wahed, M. S., S. M. El-Bermawy, K. A. El-Dougdoug, A. K. Mabrouk And M. M. Abdel-Aziz.(2013). Evaluation of one Bioagent And An InsectGrowth Regulator Against The Cotton Leafworm Using Pcr .Agric. Res., 91(2).

AlOtaibi, S. A. (2013). Mortality Responses of Spodoptera litura Following Feeding on BT- Sprayed Plants.Journal of Basic \& Applied Sciences,, 9, 195-215.

Anderson,W. R. and Fairbanks, D. J.(1990) Molecular markers: 11B. ABRS and CSIRO Publishing, Canberra and Melbourne, pp. 102-103. 51-53.

Andrews, A.T. (1981). Electrophoresis: Theory, Techniques and Biochemical and Clinical Application. Clarendon Press, Oxford, pp. 336.

Atienzar, F. A. P. Venier, A.N. Jha and M.H. Depledge(2002).Evaluation ofthe random amplified polymorphic DNA (RAPD) assay for the detection ofDNA damage and mutations.Environmental Mutagenesis. 521(1-2): 151-163.

Baurand, P.E. N. Capelli and A. Vaufleury(2015).Genotoxicity assessment of pesticides on terrestrial snail embryos by analysis of random amplified polymorphic DNA profiles. Hazardous Materials. 298: 320-327.

Beckman, J.S.and Soller, M. (1998) Resteraction fragment polymorphism and genetic improvement of agricultural species.Euphytica. 35: P. 111 - 112.

Bengochea, P. I. Sánchez-Ramos, R. Saelices, F. Amor, P. del Estal, E. Viñuela, Á. Adán, A. López, F. Budia and P. Medina.(2014).Is emamectin benzoate effective against the different stages of Spodoptera exigua (Hübner) (Lepidoptera, Noctuidae)? Agricultural and Food Research 53: 37-49.

Brewbaker, J.L. (1966). Enzyme fingerprints for the plant detective. Hawaiian Bot. Soc.Newsl. V: 1-3

Campbell PM, Yen JL and Masoumi A.(1998) Crossresistancepatterns among Lucilia cuprina (Diptera: Calliphoridae) resistant to organophosphorus insecticides. $J$ Economic Entomol. 91(2): 367-375.

El-Defrawi, M.E., A.T. Toppozada, A. Salama and S.A. ElKishen(1964). Toxicological studies on the Egyptian cotton leafworm, Prodenia litura FII. Reversion of Toxaphene resistance in the Egyptian cotton leafworm J. Econ.Entomol., 57: 593-595.

EL-Metainy, A. Y., A.Y. Abou-Youssef \& M. El-Hadad (1977). Starch Degrading isozymes in Triticumna estivum, Triticumn pyramidal, and their interspecific hybrid. Egypt.J.Genet.Cytol., 6: 375-379.
El-Sheikh,E. A. (2015). Comparative toxicity and sublethaleffects of emamectin benzoate, lufenuron and spinosad on Spodoptera littoralis Boisd(Lepidoptera: Noctuidae). Crop Protection. 67 : 228-234.

El-Sheikh, T. A. A.(2012).Comparative toxicity and biochemistry of organophosphates and pyrethroid compounds on both laboratory andfield strain of the Cotton Leafworm Spodoptera littoralis (Boisd.)biolog. Sci., 4 (1) 141-151.

Ercan, F. S. (2015). Use Of Random Amplified Polymorphic Dna (Rapd) To Detect Dna Damage Induced By Prangos Ferulacea (Umbelliferae) Essential Oil Against The Mediterranean Flour Moth EphestiKuehniella Zeller (Lepidoptera: Pyralidae). Arch. Biol. Sci., Belgrade.67 (1): 235-239.

Field LM., and Devonshire AL. (1998)Evidence that the E4 and FE4esterase genes responsible for insecticide resistance inthe aphid Myzus persicae (Sulzer) are part of a genefamily.Biochemical Journal.330: 169-173.

Finney, D.J., 1971.Probit Analysis. Cambridge University Press, Cambridge England.

Gamilhttp://www.sciencedirect.com/science/article/pii/S0570 17831100025X-cor1mailto:walaagamil@yahoo.com, W.E., F.M. Mariy, L.A. Youssef and S.M. Abdel Halim (2011).Effectof Indoxacarb on some biological and biochemical aspects ofSpodopteralittoralis (Boisd.) larvae.Annals of Agricultural Sciences.6( 2) : 121-126.

Guillemaud T, Makate N, Raymond M, Hirst B andCallaghan A. (1997).Esterase gene amplification in Culexpipiens.Insect Molecular Biology.6(4): 319-327, 1997.

Hadrys, H. M. Balick and B. Schierwater(1992).Applications of randomamplified polymorphic DNA (RAPD) in molecular ecologyMolecularEcology. 1(1): 55-63.

Hussium, S.L., Vierling, R.and Sears, R.G. (2000) Identification and napping of polymorphism in cereal based on the polymerase chain reaction // Theor. Appl. Genet. 82: 209 - 216.

Kandil, M. A.; Abdel-Aziz, N.F. and Sammour, E.A. (2003).Comparativetoxicity of chlorofluazron and leufenur on against cotton leaf worm, Spodoptera littoralis(Boisd). Egyp. J. Agric. Res. NRC, 2 :645-661.

Kristensen, M (2005). Glutathione $S$-Transferase and Insecticide Resistance inLaboratory Strains and Field Populations of Musca domestica.JournalofEconomic Entomology.98( 4) :1341-1348.

Kuhr, R.J., Dorough, H.W(1976). Carbamate Pesticides: Chemistry Biochemistry, and Toxicology. CRC Press, Cleveland, OH, USA.

Marcili, A. L. Lima, M. C. Jr., A. C. V. Junqueira, H. H. VeludoF. M. D. Silva, M. Campaner, F. Paiva, V. L. B. Nunes and MM. G. Teixeira.(2009). A new genotype of Trypanosoma cruzi associated with bats evidenced by phylogenetic analyusing SSU rDNA, cytochrome $b$ and Histone H2B genes and genotyping based on ITS1 rDNA. Parasitology . 136 (6): 641-655. 
Mironenko, N. E. Timopheeva, L. Mikhailova, D. Kopahnke, I.Krämer and F. Ordon.(2007). Intraspecific genetic diversity of Pyrenophrepentis (Died.)Drechs. (Drechslera tritici-repentis[Died.]Shoem.)detectedby random amplified polymorphic DNA assays. Phytopathology and Plant Protection. 40( 6): 431-440.

Muthusamy, Shivakumar, Karthi and Ramkumar. (2011). Pesticide detoxifying mechanism in field population of Spodoptera litura (Lepidoptera: noctuidae) from South India. Biolog. Sci., 3 (1): 51- 57.

Nascimento AP and Bicudo HEMD. (2002)Esterase patterns and phylogenetic relationships of Drosophila species in the saltans subgroup (saltans group).Genetica. 114(1): 4151 .

Oakeshott, JG, van Papenrecht EA, Boyce TM, Russell RJ and Healy MJ. (1993) Evolutionary genetics of Drosophila esterases.Genetica. 90: 239-268.

Rohlf, F.J. (2000).On the use of shape spaces to compare morphometric method. Hystrix, Italian J. Mammology (n.s.), 11(1): 8-24.

Sharma, V.R. K. Shukla, N. Saxena, D.Parmar, M. Das,andAdhawan(2009).DNA damaging potential of zinc oxide nanoparticles in human epidermal cells. Toxicology Letters. 185( 3): 211-218.

Shaw, M.D. and A.L. Kaen, (1967). Starch gel electrophoresis of enzymes Biological Reserch Laboratory Publication. Hawthron CenterNorthville, Michigan, USA.

Soliman, S. S. B. A. Ali, and M. M. M. Ahmed.(2003). Genetic comparisons of Egyptian date palm cultivars (Phoenix dactylifera L.) by RAPD-PCR. African Journal of Biotechnology.1 2 (4) :1684-5315.
Tanksley, S.D., N .D. Young, AH.Paterson, and M.W. Bonierbale(1989). RFLP mapping in plant breeding: New tools for an old science. Bio/Techn. 7:257-264.

Taskin, V. and Kence M. (2004)The genetic basis of malathion resistance in housefly (Musca domestica L) strains from Turkey. Russian Journal of Genetics. 40: 1475-1482.

Vojoudi, S. M. Saber, M.J.Hejazi, R and T.Hassanloui.(2011).Toxicity of chlorpyrifos, spinosad and abamectin on cotton bollworm, Helicoverpa armigera and their sublethal effects on fecundity and longevity.Bulletiof Insectology 64 (2): 189-193.

Welsh, J and M, McClelland.(1990).Fingerprinting genomes using PCRwith arbitrary primers. Nucleic Acids Res. 18(24): 7213-7218.

Whitkus, R. J. Doebley, and J. F. Wendel.(1994).Nuclear DNA markerin systematics and evolution.DNA-based markers in plants.1: 116-141.

Willcocks, F. C. and S. Bahgat (1937). The insects and related pests of Egypt Royal Agricultural Society, Vol.I, Part II, $785 \mathrm{p}$.

Williams, J.G.K., A.R. Kubelik, K.J. Livak, J.A. Rafalski and S.V. Tingey(1990). DNA polymorphisms amplified by arbitrary primers are useful genetic markers. Nucl. Acids Res. 18:6531-6535.

Youssef, M.K., E.A. Badr, A. Abou-Youssef. \& S. El-Deeb (1989).Comparative electrophoretic pattern of isozymes in four species of tilapia, third Egyption British conference on Animal, Fish and Poultry production.Alexandria, 7-10 October, 849-858. 


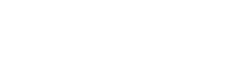

كهاءه إلستخدلم بهض المبيدل الحيثة عل دوة ورق الفلن إعتمادا عل المعاملت الكيموحيوية

\section{والجزبئية}

لحمد اللسيد محمد خالد، نادر رجب عبد اللسلم محمد

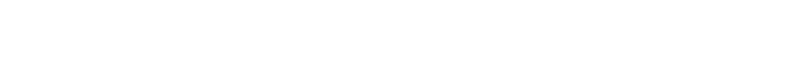
وزياة نشط الأنزيمك مل أنزيم الأستيريز.

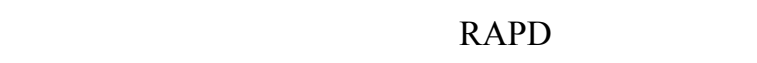

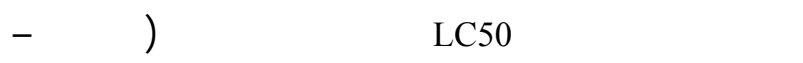
سيكلون- تيرلجارد- بروكليم) لقندير مدي الضرر الحادي

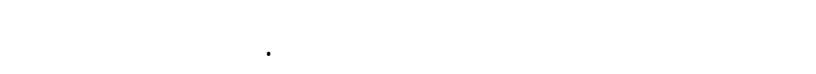

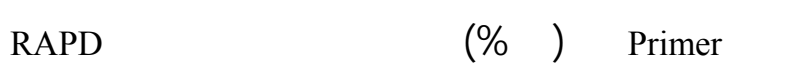

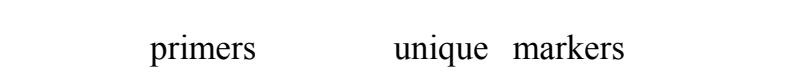

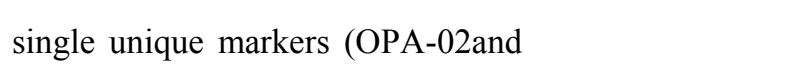

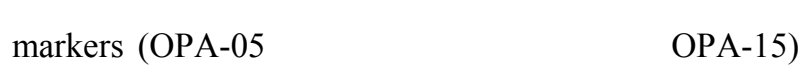

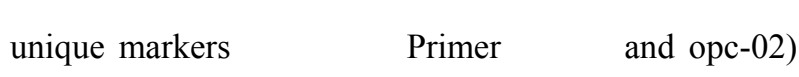

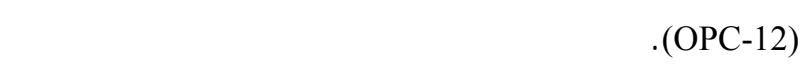

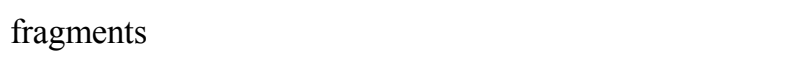

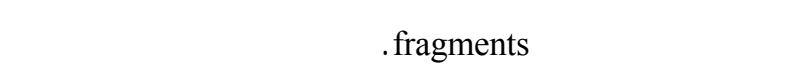

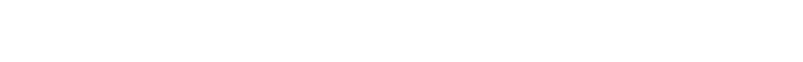
أوضحت النتائج المدروسة أن مبيد البروكليم قدسب زيب زياة النياة تنظيم التعبير الجيني.
لجريت الدرلسة لقييم كفاءة بعض المبيدات الهشر يـ ــة

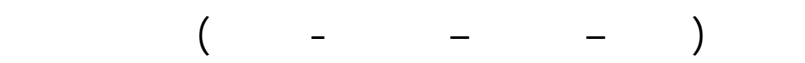

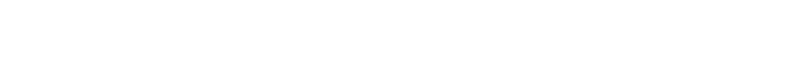

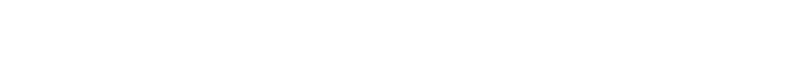
المختبرة. وقد م تحديد التركيزالنصف المميت للعمر اليرقى المقل

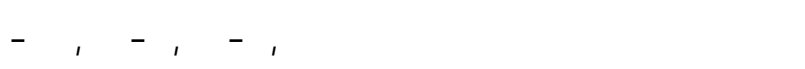

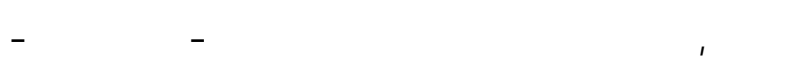

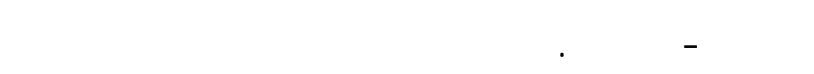

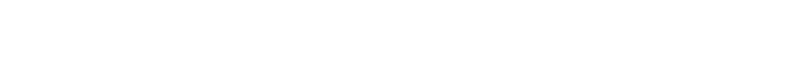
النصفي المميت وهو IV I · , · جزءء في المليون.

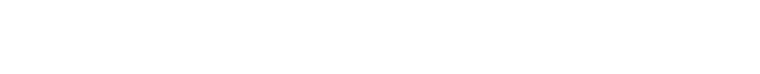

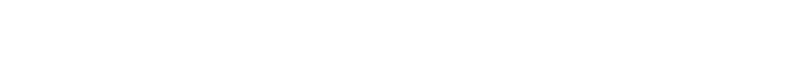

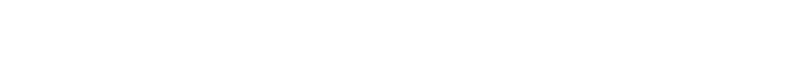

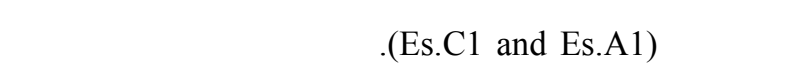

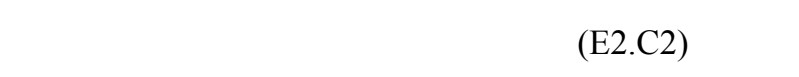

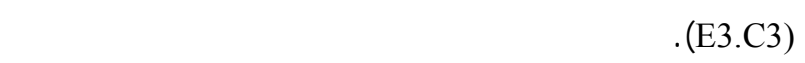

